MONOGRAPH OF THE OXYTRICHIDAE

(CILIOPHORA, HYPOTRICHIA) 


\section{MONOGRAPHIAE BIOLOGICAE}

VOLUME 78

Series Editors

H. J. Dumont and M. J. A. Werger 


\title{
Monograph of the Oxytrichidae (Ciliophora, Hypotrichia)
}

\author{
by \\ HELMUT BERGER \\ Consulting Engineering Office for Ecology, \\ Salzburg, Austria
}


A C.I.P. Catalogue record for this book is available from the Library of Congress.

ISBN 978-94-010-5958-9 ISBN 978-94-011-4637-1 (eBook)

DOI 10.1007/978-94-011-4637-1

Printed on acid-free paper

All Rights Reserved

(C) 1999 Springer Science+Business Media Dordrecht

Originally published by Kluwer Academic Publishers in 1999

Softcover reprint of the hardcover 1st edition 1999

No part of the material protected by this copyright notice may be reproduced or utilized in any form or by any means, electronic or mechanical, including photocopying, recording or by any information storage and retrieval system, without written permission from the copyright owner. 


\section{Dedication}

This book is dedicated to my family, Elisabeth, Magdalena, Eva, Helena Valentina and my parents, Maria and Johann $†$ Berger 


\section{Contents}

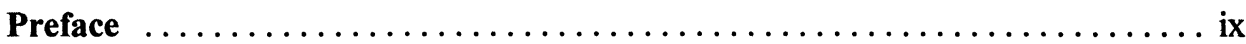

Acknowledgements $\ldots \ldots \ldots \ldots \ldots \ldots \ldots \ldots \ldots \ldots \ldots \ldots \ldots \ldots \ldots \ldots \ldots \ldots \ldots \ldots \ldots \ldots$

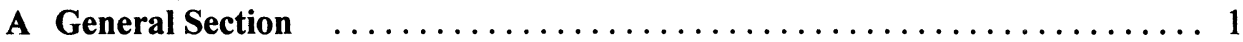

1 Morphology, Biology, and Terminology $\ldots \ldots \ldots \ldots \ldots \ldots \ldots \ldots \ldots$

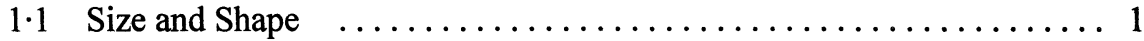

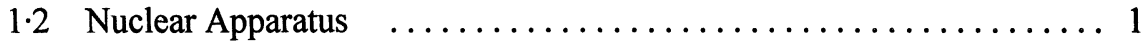

1.3 Contractile Vacuole and Cytopyge $\ldots \ldots \ldots \ldots \ldots \ldots \ldots \ldots \ldots$

1.4 Cytoplasm and Colouring $\ldots \ldots \ldots \ldots \ldots \ldots \ldots \ldots \ldots \ldots \ldots \ldots$

1.5 Cortical Granules $\ldots \ldots \ldots \ldots \ldots \ldots \ldots \ldots \ldots \ldots \ldots \ldots \ldots . \ldots \ldots$

1.6 Movement ................................... 12

1.7 Somatic Infraciliature and Ultrastructure $\ldots \ldots \ldots \ldots \ldots \ldots \ldots \ldots \ldots$

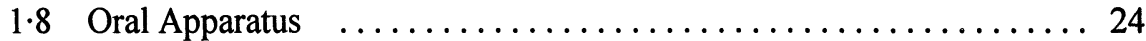

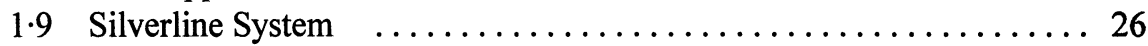

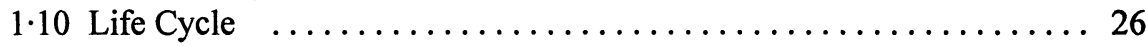

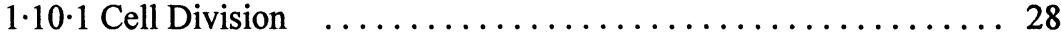

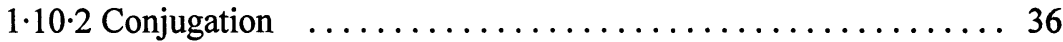

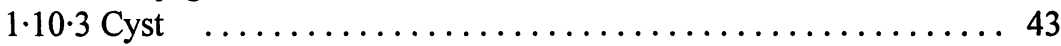

$1 \cdot 10 \cdot 4$ Reorganisation, Regeneration, Doublets $\ldots \ldots \ldots \ldots \ldots \ldots . \ldots 49$

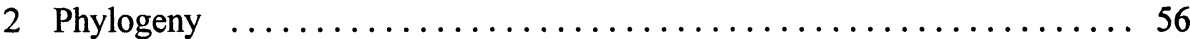

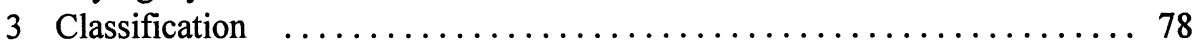

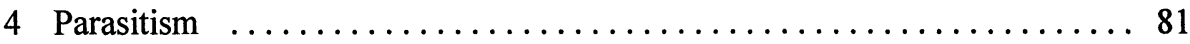

5 Ecology, Occurrence, and Geographic Distribution $\ldots \ldots \ldots \ldots \ldots . . .68$

6 Collecting, Culturing, Observing, and Staining of Oxytrichid Ciliates $\ldots . .88$

$6 \cdot 1$ Collecting and Culturing $\ldots \ldots \ldots \ldots \ldots \ldots \ldots \ldots \ldots \ldots \ldots . \ldots \ldots$

$6 \cdot 2$ Observing Living Hypotrichs $\ldots \ldots \ldots \ldots \ldots \ldots \ldots \ldots \ldots \ldots$

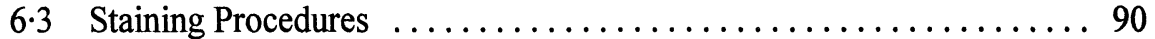

$6 \cdot 3 \cdot 1$ Feulgen Nuclear Reaction $\ldots \ldots \ldots \ldots \ldots \ldots \ldots \ldots . \ldots 1$

6.3.2 Supravital Staining with Methyl Green-Pyronin $\ldots \ldots \ldots \ldots . .91$

6.3.3 Protargol Methods $\ldots \ldots \ldots \ldots \ldots \ldots \ldots \ldots \ldots . \ldots . \ldots 2$

6.4 Preparation for Scanning Electron Microscopy ............ 99

7 Summary of New Taxa Described in this Book and of Nomenclatural Acts 100

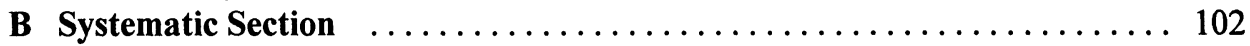

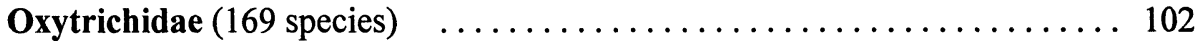

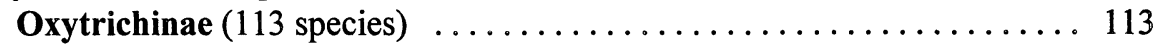

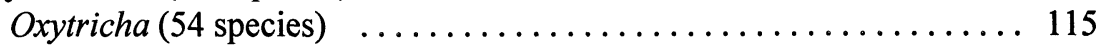

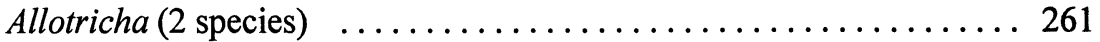

Cyrtohymena $(15$ species $) \quad \ldots \ldots \ldots \ldots \ldots \ldots \ldots \ldots \ldots . \ldots . \ldots . \ldots 279$

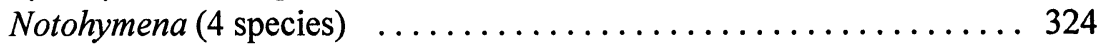

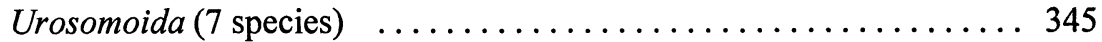

Gonostomum (4 species) $\ldots \ldots \ldots \ldots \ldots \ldots \ldots \ldots \ldots \ldots \ldots \ldots$

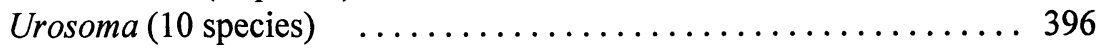

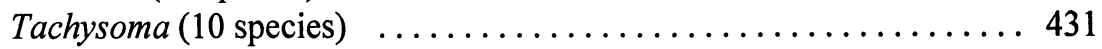

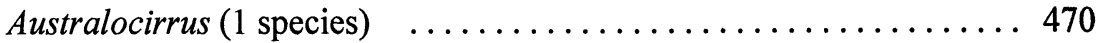


Onychodromopsis (2 species) $\ldots \ldots \ldots \ldots \ldots \ldots \ldots \ldots \ldots \ldots 45$

Rubrioxytricha (2 species) $\ldots \ldots \ldots \ldots \ldots \ldots \ldots \ldots \ldots \ldots \ldots \ldots$

Parurosoma (1 species) ..................... 491

Pseudostrombidium (1 species) $\ldots \ldots \ldots \ldots \ldots \ldots \ldots \ldots \ldots \ldots 4$

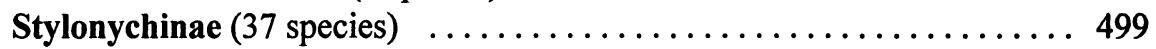

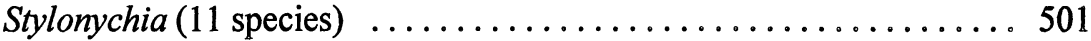

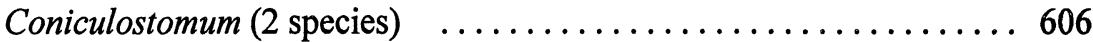

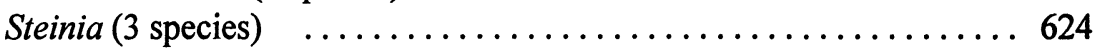

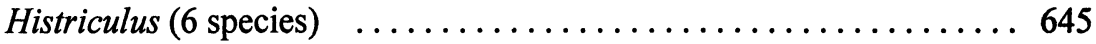

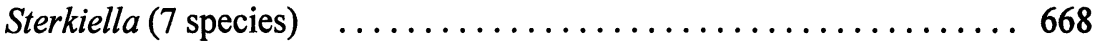

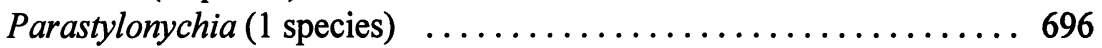

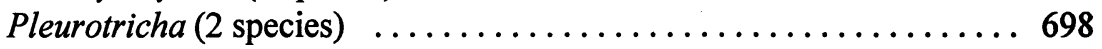

Rigidocortex (1 species) ..................... 717

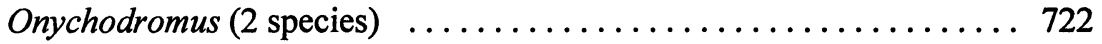

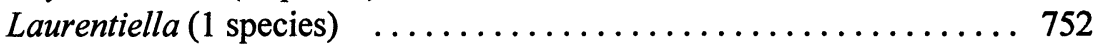

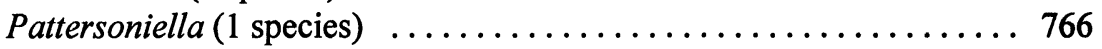

Taxa of Unknown Position within the Oxytrichidae $\ldots \ldots \ldots \ldots \ldots \ldots 77$

Ancystropodium (1 species) $\ldots \ldots \ldots \ldots \ldots \ldots \ldots \ldots \ldots \ldots \ldots \ldots 77$

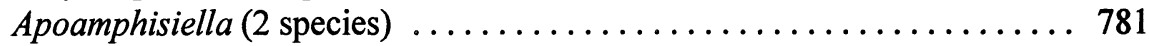

Gastrostyla (8 species) $\ldots \ldots \ldots \ldots \ldots \ldots \ldots \ldots \ldots \ldots \ldots \ldots \ldots \ldots$

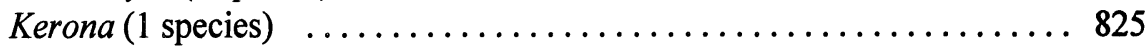

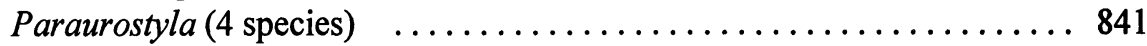

Parentocirrus (1 species) $\ldots \ldots \ldots \ldots \ldots \ldots \ldots \ldots \ldots \ldots \ldots$

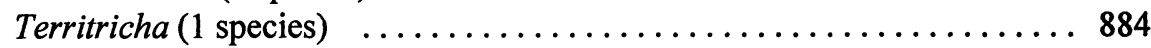

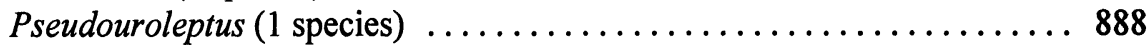

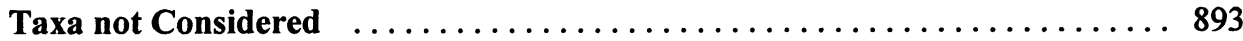

Illustrations of Species Indeterminata and Insufficient Redescriptions . . . 895

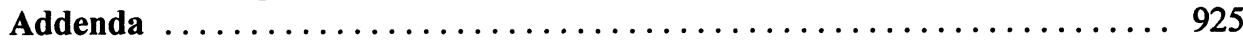

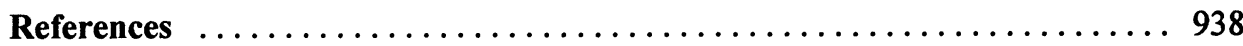

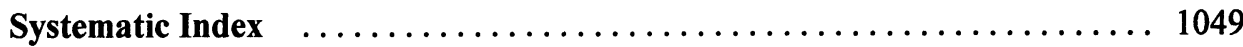

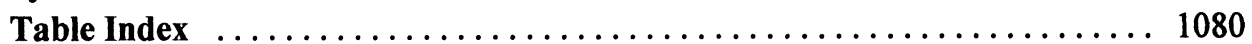




\section{Preface}

I have written this book because there is, as in almost all supraspecific ciliate taxa, an urgent need for an up-to-date revision of the oxytrichids, which are common in terrestrial, limnetic, and marine biotopes. The last comprehensive, illustrated guides to this group of hypotrichs were provided by KAHL (1932) and STLLER (1974b); however, as regards synonymy and faunistics, these works are outdated and not as detailed as EHRENBERG's outstanding book from 1838. In KAHL's revision, the oxytrichids sensu stricto are described on about 30 pages, whereas in the present book the systematic section comprises about 830 pages. This extraordinary increase in page number is mainly due to the following points: (i) Species number increased from about 80 in KAHL to about 170 in the present book. (ii) KAHL usually provided only a single illustration of each species, whereas almost all published illustrations on oxytrichid ciliates are included in my book. (iii) Modern, phylogenetic systematics of oxytrichids without morphogenetic data is impossible; consequently, almost all detailed descriptions, usually dealing with the type species, have been included. (iv) Synonymy is discussed, and not only mentioned, as is unfortunately usual. (v) Modern descriptions of oxytrichids, and ciliates in general, are much more comprehensive than the descriptions by KAHL; note, however, that STEIN's (1859b) description on, for example, Stylonychia mytilus is 14 (folio-sized) pages long and includes 34 incomparable live drawings on 3 plates! (vi) Almost all physiological, ecological, and faunistic literature available on each species is mentioned; the present book is therefore not only a "field guide", but also a reference book.

Most species treated in the present book have a highly characteristic 18 frontalventral-transverse cirral pattern strongly indicating that they are a monophylum. However, the sole apomorphy of the last common ancestor of all species revised is a different character, namely the fragmentation of a dorsal kinety. This feature, which can be clearly seen only during morphogenesis, was recognised rather late because it needs silver impregnation. It is so curious that convergent evolution is very unlikely.

From 1758 to 1997 about 440 species were described in oxytrichid genera, however, only 169 species are considered as valid in the present book. Five species were discovered by O. F. MólLER in the second half of the 18 th century, 39 species were described in the 19th century, and the majority was found after the turn of the century. The most productive and prominent workers on oxytrichid taxonomy are, in chronological order, EHRENBERG, STEIN, STOKES, KAHL, and FOISSNER; however, many others provided important contributions to the alpha-taxonomy of the oxytrichids. 82 species are synonyms, the synonymy rate is thus about $48 \%$. Nine species - all of them are very common and known for a long time - have more than two synonyms. However, $81 \%$ of the valid species have no synonym. More than 140 species cannot be identified from the original description, that is, they are species indeterminata. 32 genera are considered as valid; 12 of them are monotypic, five contain 10 or more species each. These comprehensive genera include $60 \%$ of all species. Oxytricha, the most voluminous group, comprises 54 species; how- 
ever, only a part of them is described by modern methods, making the identification of these "inconspicuous" species rather difficult.

This revision was my "leisure pursuit" for many hundreds of hours distributed over a period of 13 years. Originally it was planned as volume 6 (Hypotrichia) of the Protozoenfauna (Gustav Fischer Verlag), a detailed monograph of all freshwater protozoa. However, only few groups (Suctoria, Urceolaridae, Nackte Rhizopoda, Heliozoea, Colpodea) were published before this series was suspended in 1996. Fortunately, Prof. Dr. H. J. Dumont (Ghent, series editor of the Monographiae Biologicae) and Kluwer Academic Publishers were interested in my manuscript.

Now, I hope that this revision, whatever its shortcomings, is of more or less great help to all who deal with oxytrichids. Hopefully, they will be encouraged to tackle the many remaining problems, great and small, that is, redescribe poorly defined species, elucidate their morphogenesis, ultrastructure, physiology, molecular biology, ecology, and their phylogenetic relationships. Furthermore, many species in freshwater, soil, and marine habitats in Europe and especially in the other continents are waiting to be discovered and thoroughly described.

Salzburg, January 1999

Helmut Berger 


\section{Acknowledgements}

I am indebted to several people for helping me prepare this book, in particular my mentor, Prof Dr Wilhelm FoIssNeR (University of Salzburg, Austria) for supplying many original micrographs and faunistic data and for his help with the literature; to Prof $\mathrm{Dr}$ Christian BARDELE (University of Tuebingen, Germany), Dipl Biol Hubert BlaTtereR (Amt der Oberösterreichischen Landesregierung, Linz, Austria), Dr Ulrich BurtKaMP (Stawa Lippstadt, Germany), Mr Josef DiecKmann $\uparrow$ (Münster-Wolbeck, Germany), Dr Komal KaMra (University of Delhi, India), Prof Dr Martin Schlegel (University of Leipzig, Germany), Dr Oliver SkIBBE (University of Berlin, Germany), Dr Weibo Song (Ocean University of Qingdao, China), Mr Hans-Jürgen Voss (Bottrop, Germany), and Dr Norbert WILBERT (University of Bonn, Germany) for supplying micrographs and illustrations; to the staff at the Salzburg University Library for their patient assistance in locating the vast literature on hypotrichs; and to MSc Eric STROBL (Salzburg, Austria) for improving the English. I also wish to acknowledge the generosity of the Kluwer Academic Publishers (especially Ms Angela Jones, Bioscience Division, and Drs René Mus, Publishing Editor) and the Series Editor, Prof Dr Henri J Dumont (The State University of Ghent, Belgium), for printing this book.

The figures are either originals or reproductions from the literature of the past 220 years. I give sincere thanks to the following publishers who largely freely granted permission to use published drawings and photographs: Akadémiai Kiadó, Budapest (Symposia Biologica Hungarica); American Microscopical Society, Lawrence (Transactions of the American Microscopical Society); Bayerisches Landesamt für Wasserwirtschaft, München (Informationsberichte des Bayerischen Landesamtes für Wasserwirtschaft); Biologiezentrum des Oberösterreichischen Landesmuseums, Linz (Kataloge des O.Ö. Landesmuseums; Stapfia); Biopress Limited, Bristol (Progress in Protistology); Cambridge University Press, Cambridge (Biological Reviews; The Cell Cycle in Development and Differentiation); CNRS Editions, Paris (Archives de Zoologie Expérimentale et Générale; Protistologica; charged); Company of Biologists Ltd., Essex (Journal of Embryology and experimental Morphology); CSIRO Publishing, Collingwood (Invertebrate Taxonomy); Debrecen Agricultural University, Debrecen (Debreceni Agrártudományi Egyetem Tudományos Közleményei); Duncker \& Humblot GmbH, Berlin (Zoologische Beiträge); Editions Elsevier, Paris (Annales des Sciences Naturelles - Zoologie); Erik Mauch Verlag, Dinkelscherben (Lauterbornia); Gustav Fischer Verlag, Jena, Stuttgart (Archiv für Protistenkunde; European Journal of Protistology; Limnologica; Zoologischer Anzeiger; Zoologisches Jahrbuch Systematik); Institut für landwirtschaftliche Zoologie und Bienenkunde, Bonn (Arbeiten aus dem Institut für landwirtschaftliche Zoologie und Bienenkunde); Instituto de Biología UNAM, Mexico (Manual de ciliados psamofilos marinos y salobres de Mexico; Anales del Instituto de biologia. Universidad de México); Naturhistorischer Verein der Rheinlande und Westfalens, Bonn (Decheniana); Oxford University Press, Tokyo (Journal of Electron Microscopy); Polish Academy of Science, 
Nencki Institute of Experimental Biology, Warsaw (Acta Protozoologica); Society of Protozoologists, Lawrence (Guide to the Protozoa; The Journal of Protozoology); Springer-Verlag, Heidelberg, Wien (Biology and Fertility of Soils; Chromosoma; Oecologia; Polar Biology; Results and Problems in Cell Differentiation; Sitzungsberichte der Österreichischen Akademie der Wissenschaften); Taylor \& Francis Ltd., London (The Journal of Natural History); The Norwegian Academy of Science and Letters, Oslo (Zoologica Scripta); The Korean Society of Systematic Zoology, Jeonji (The Korean Journal of Systematic Zoology); The Zoological Society of Korea, Seoul (Korean Journal of Zoology); University of St. Petersburg, Zoological Institute, St. Petersburg (Zoosystematica Rossica); Wiley-VCH, Weinheim (Internationale Revue der gesamten Hydrobiologie); Wissenschaftliche Verlagsgesellschaft $\mathrm{mbH}$, Stuttgart (Cytobiologie). I also ask understanding from those publishers whose permission was not obtained due to my oversight. Specific acknowledgements are made in the figure legends: there are named the authors of the papers in which the illustrations originally appeared.

Finally, a special acknowledgement should be made to my wife, Elisabeth, for her understanding of this time-consuming and expensive pursuit, and to my daughters, Magdalena, Eva and Helena, for giving up time that belonged to them. 